\title{
Factors Affecting on Participatory Forest Management in Kavrepalanchok District, Nepal
}

\author{
Yogesh Ranjit ${ }^{1}$
}

\begin{abstract}
The paper deals with major factors affecting on people'sparticipation in forest protection and management activitiesin the Hill area of Nepal. Local people participate in forestry programmes basically for improving quality, quantity, and density of foreststhat ultimatelyhelp in continuouslyavailability of the basic forest products for their livelihood and socio-economic development. The nature and level of people's participation is highly determined by gross household incomeand socio-economic factors. A multiple log regression analysisis used to examine the level of people's participation as dependent variable and gross household income along with other socio-economic factors as independent variables. Correlation coefficients, coefficient of determinants, adj-coefficient of determinants, $t$-test, $F$-test and $D$-W test are the major tools used for data analyses. The study found that as people received more forest products and other benefits from forest protection and management in short and long term, local people significantly participate in forestry programms. As women, poor people and disadvantage gropes (DAGs) of the society are the prime users of forests and forest products, they have been directly involved and also gradually increasing in forestry activities in the study area.
\end{abstract}

Key Words: Kavrepalanchok, People's participation, Forests, Forest products,Forest user groups, Gross household income, Women, Poor and DAGs.

\section{Introduction}

Participatory forest management(PFM) is often known as the forestry programme initiated by the government with the participation of local people living in and around the forests. It is also defined as the practice of forestry programme where trees are planted on common land that provides a direct benefits of the people living in and around the forests for their livelihood like timber, pole, fuel wood, twigs,fodder, grass, leaf litter, foods,non-timber forest products (NTFPs) for building construction, agricultural tools, livestock keeping, and forest based industries, etc.It has been described as 'Village Centered with Technical Inputs' programme (Gilmour, King \& Fisher, 1987). It is the 'Forestry of the people, for the people

1 Dr. Ranjit is an Associate Professor at the Central Department of Economics, T. U. Kirtipur. Email:yogeshr777@yahoo.com 
and by the people' (Karki, 2003).Similarly, forests also provide vital role for bio-diversity conservation, environmental protection and ecological balance of the nation.

FAO defined PFM as a process by which the rural poor are able to organize themselves through their own organization and they are able to identify their own needs, share in the design implementation, and evaluation of the participatory action (Anon, 1994).PFM has been spreading all over the world with different names but similar objectives. It does not simply meanof voluntary contribution of local people in forestry programmes. It largely depends upon the socio-economic condition of the local people and it is bound to vary from place to place.

The willingness to participate in forest protection and management work generally depends upon motivation arising from growing shortage of forest products (Arnold \& Campbell, 1985). Full participation of people consists of the four interrelated process like planning (creating the ideas), decision making (deciding whether or not to do it), implementing (doing the work) and evaluation (making a value judgment).But decision making is considered as most important among the all (Anon, 1994). There are some crucial conditions for meaningful participation of local people in forests protection and management work like sense of ownership, awareness of collective issues, sufficient incentive to give time and labour in lieu of the intermediate and final forest products etc. Government,staff of forestry department, internal and external forestry experts, NGOs, and INGOs can be involved togetherand play a significant roleas an advisor, facilitator, technical and financial supporter in forestry programmes for effective participation of people. However, to success the forestry programme, local people must be involved as a prime agent and it is not only in the form of physical standing but also in managerial level of decision making (Joshi, 1997).

Traditionally,PFMis very common in Nepal as there were many traditional informal and indigenous local committees working for forest protection and management work. So, it refers to the absolute involvement of local communities in any specific forestry programmes from planning, implementing, monitoring, evaluation, sustainable operation and maintenance of forests. The major aims of people's participation in forest management work are to continuous supply of the basic forest products to forest users, their socio-economic development, and to improve the condition of forests both in quality and quantity. So, the local people are prime users and also managers of forests and forest products. There are various forms and modals of PFMthat may vary from country to country based on their political, socio-economic, and cultural practices like community forestry (CF), leasehold forestry, collaborative forestry, join forest management (JFM), social forestry, and agro-forestry etc.

Community forestry is defined as a situation that intimately involves local people in forestry activities (FAO, 2000).It can be defined in terms of control and management of forest resources by the rural people who basically use them for domestic purposes and as an integral part of their farming systems (Gilmour \& Fisher, 1991).Infact, a community forest is a part of a national forest that has been handed over to a local user group for its development, conservation and utilization for the collective interest.CFP is very popular in Nepal in which there is an active involvement of the local people in forest protection and management work in the country.But it has formally and legally been recognized in Nepal 
as a key element in forestry programme only since mid-1970 through various forest plans, policies, acts, regulation and guidelines etc.By 2018, there are 22,266 CFUGs working in 22,37,670 hectors forests with the beneficiariesof 29,07,871 households (DoF, 2018).

\section{Review of Literature}

Since the late $20^{\text {th }}$ century, there was a dramatic transformation in forest uses and management systemin the world. The 'Jakarta Declaration' of the 'Eighth World Forestry Congress' in 1978 projected serious problems in supply of forest products and its utilization. Consequently, the century-old centralized and controlled forest management system shifted to decentralization in the form of people's participation (Houghton, 1990).

The main reasons for shifting top-down to bottom-up approach will be the globally changes in economic liberalization policies, failure of past forest management practices, approaches of thegovernment, and pressure from donor agencies for greater accountability and transparency (Thompson.1995). Infact,the government alone cannot successfully protect and manage the forests without involving local people (Mehta, 2001).There is a vital importance of bottom-up planning in the forestry programmes that involves and consults each and every stakeholder (Joshi, 2004).

South Asian countries still have been pursuing indigenous forests management system through people's participation based on their bio-physical and socio-economic condition (ICIMOD, 1995). Nepal has also launched people's participation programme in late 1970's in the name of 'Community Forestry Programme (CFP)' and made a significant progress in development of quantity, quality, and density of forests (Joshi, 2004). The government of Nepal passed legislation in 1978 to handover the substantial amount of national forests to local communities for forest protection and management through the Panchayat forests (Panchayat is a lowest level of local government at that time). Then, the focus was shifted from Panchayats to the community forest user groups (CFUGs) with more authority and responsibility with the community Forest Act-1993 and Forest Regulation-1995. Such actandregulation provided local people significant control in the management and harvesting of forest resources (Ranjit, 2014). Because of this progressive act and regulation, community forests hand over process has speeded up rapidly during the last twenty years period.These act and regulation have made FUGs more strong as they can develop their own operational plan, set the prices of forest products, and determine the use the surplus income. Thought trees and NTFPs are legally belonging to forest user groups, ownership of the forest land remaining with the state so that the state can take back of the community forest land if the terms and conditions of handover are not met by the FUGs.

But, in many cases, forest products have not been equally distributedto poor, women, landless and DAGsdue to less involvement in decision-making positions (Shrestha \& Sharma, 2004). Although the 'Community Forestry Development Guidelines - 2001' highly emphases on significantly participationof womenand DAGs, their participation in forest protection, management and decision-making is still low but gradually increasing over time period. 
People's participation in forest protection and managementwork has become most effective vehicle for income and employment generation in Hilly districts of Nepal (Ranjit, 2015).

CFP in Nepal is successful in increasing the greenery of degraded sites, biodiversity and environmental situation forming, local level institutions for revenue management and improving the supply of forest products to farmers in the Hills of Nepal (Acharya, 2003). Nepal has made a significant progress in development of forest resources through the people's participation in forest protection and management activities in the name of CFP (Joshi, 2004). The forest use and management would be integrated through the active cooperation and participation of the local people living in and around the forests (Nadkarni, 1989).The integration of forest use and management with strategies of economic development is possible only through the active cooperation and participation of the local people (Kandel and Subedi, 2004). The forest management programmes cannot be successfully done without involving people and strong support of local institutions and NGOs (Mehta, 2001). Therefore, the government, I/NGOs and other stakeholders should play the advisory role as a facilitator and technical supporter for effective people's participation in forestry programmes (Ranjit, 2015).

\section{Objectives of the Study}

The general objective of the study is to analyze the behaviour of people's participation in forest protection and management activities in the Hill region of Nepal. However, the specific objective of the study is to analyze the general ways of people's participation and its major determinants in the study area. So, the paper basically deals with the factors affecting on participation of people living in and around the forests in forest protection and management work in the study area.

\section{Study Area and Profile of Forest User Groups under Study}

Kavrepalanchowk (Fig.1) is one of the 13 districts of Bagmati Province of Nepal (Fig.-2) thatconsists of 6urban and 7 rural municipalities.It spreads between $27^{0} .20^{\prime}$ to $27^{0} .35^{\text {! North }}$ latitude and $85^{\circ} .24$ ! to $85^{\circ} 59$ !'East longitude. The elevation of the district varies from 1007 $\mathrm{m}$. to $3018 \mathrm{~m}$.It has sub-tropical and temperate climate. Theheadquartersof the district is Dhulikhel located at $30 \mathrm{~km}$. east from capital city of Kathmandu. The district is surrounded by Ramechhap in the east, Dolkha in the north-east, Sindhu Palchok in the north, Lalitpur and Bhaktapur in the west, Makwanpur district in the south, and Sindhuli in the east-south respectively (CBS, 2014). The total geographical area of the district is 140486ha. (1446 $\mathrm{km}^{2}$ ) out of which the forest area covers 39,565 ha.that becomes 28.16 percent of total area coverage of the district (DFO, 2018). Total population of the district is $3,85,672$ out of which $1,88,947$ (48.99 percent) males and 1,96,725 (51.01 percent) females with 70509 households. The average household size is 5.47 with the population density is 276 per sq. $\mathrm{km}$. (CBS, 2012).Tamang, Brahmin, Newar, Chhetri are the main caste group in the district.Potato and milk is the main cash crops of the district that is one of the biggest suppliers of them to the Kathmandu Valley. 
Figure 1: Map of Kavrepalanchwok District

Figure 2: Map of Nepal
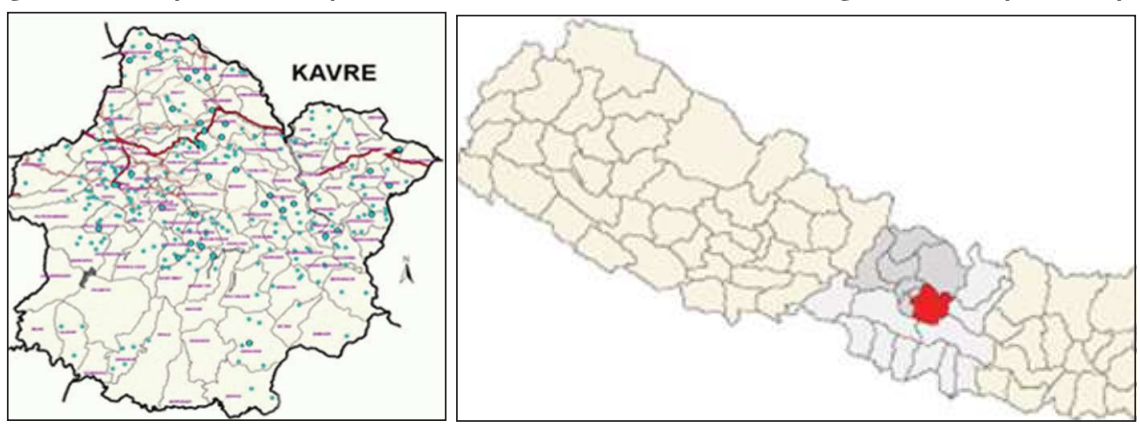

Source: www.wikipedia.org

There are 572 FUGs in Kavrepalanchok district working in 29,008ha. Forests (i.e.73.32 percent of total forest areaof the district) with the beneficiaries of $63908 \mathrm{HHs}$ by 2018 (DoF, 2018). Outof which 5 FUGs from the district have been randomly selected as sample FUGs for the study. These FUGs are BhagabanThumki FUG, Hile Jaljale FUG, Kajiko Dhaireni FUG, Thulophaka-3 FUG, and Dhaneshwor Baikiwa FUG. A brief socio-economic, bio-physical and institutional profile of those selected FUGs can be shown with the help of table1.

Table 1: Profile of Forest User Groups under Study

\begin{tabular}{|c|c|c|c|c|c|c|}
\hline $\begin{array}{l}\mathbf{S} \\
\mathbf{N}\end{array}$ & $\begin{array}{l}\text { Name of FUGs } \\
\text { Particulars }\end{array}$ & $\begin{array}{c}\text { Bhagaban } \\
\text { Thumki }\end{array}$ & $\begin{array}{c}\text { Hile } \\
\text { Jaljale }\end{array}$ & $\begin{array}{c}\text { Kajiko } \\
\text { Dhaireni }\end{array}$ & $\begin{array}{c}\text { Thulo } \\
\text { Pakha -3 }\end{array}$ & $\begin{array}{c}\text { Dhaneshwor } \\
\text { Baikiwa }\end{array}$ \\
\hline 1 & Date of Registration & $1990(2047)$ & $991(2048)$ & $1993(2050)$ & $1991(2048)$ & $2002(2060)$ \\
\hline 2 & Forest Area Covered & 29 ha & 118 ha & $182 \mathrm{ha}$ & 23 ha & $43 \mathrm{ha}$ \\
\hline 3 & Forest Types & \begin{tabular}{|l|} 
Natural + \\
Plantation
\end{tabular} & \begin{tabular}{|l|} 
Natural + \\
Plantation
\end{tabular} & \begin{tabular}{|l|} 
Natural + \\
Plantation
\end{tabular} & $\begin{array}{l}\text { Natural + } \\
\text { Plantation }\end{array}$ & $\begin{array}{l}\text { Natural + } \\
\text { Plantation }\end{array}$ \\
\hline 4 & $\begin{array}{l}\text { Major Animal \& Bird } \\
\text { Species Availability }\end{array}$ & $\begin{array}{l}\text { Porcupine, } \\
\text { Fox Forest } \\
\text { cock, }\end{array}$ & $\begin{array}{l}\text { Tiger, Fox, } \\
\text { Forest cock, } \\
\text { dove, }\end{array}$ & $\begin{array}{l}\text { Tiger, Fox } \\
\text { Leopard } \\
\text { Dove, Eagle, }\end{array}$ & $\begin{array}{l}\text { Tiger, Dove, } \\
\text { Parrot, Fox, } \\
\text { cock }\end{array}$ & $\begin{array}{l}\text { Tiger, Fox } \\
\text { Leopard, } \\
\text { cock, Parrot }\end{array}$ \\
\hline 5 & $\begin{array}{l}\text { Major tree \& fodder } \\
\text { species Availability }\end{array}$ & $\begin{array}{l}\text { Salla, Katus, } \\
\text { Chilauni, } \\
\text { Setikath }\end{array}$ & $\begin{array}{l}\text { Salla, Katus } \\
\text { Chilauni, } \\
\text { Khanun }\end{array}$ & $\begin{array}{l}\text { Saal, Salla, } \\
\text { Katus, } \\
\text { SimalKatus }\end{array}$ & $\begin{array}{l}\text { Salla, } \\
\text { Setikath } \\
\text { Chilauni, }\end{array}$ & $\begin{array}{l}\text { Salla,katus, } \\
\text { Gurans,Katus }\end{array}$ \\
\hline 6 & $\begin{array}{l}\text { Major NTFPs } \\
\text { Availability }\end{array}$ & $\begin{array}{l}\text { Bamboo, } \\
\text { Aiselu, } \\
\text { NigaloKhoto }\end{array}$ & $\begin{array}{l}\text { Dhasigare, } \\
\text { Nigalo, } \\
\text { Chttro }\end{array}$ & $\begin{array}{l}\text { Dhasigare, } \\
\text { Gurans, } \\
\text { Chttro }\end{array}$ & $\begin{array}{l}\text { Dhasigare, } \\
\text { Kaphal, } \\
\text { Chttro } \\
\end{array}$ & $\begin{array}{l}\text { Dhasigare, } \\
\text { Bamboo, } \\
\text { Gurans }\end{array}$ \\
\hline 7 & $\begin{array}{l}\text { Major medicinal plant } \\
\text { availability }\end{array}$ & \begin{tabular}{|l|} 
Dhasigare, \\
Chutro
\end{tabular} & $\begin{array}{l}\text { Amala, } \\
\text { Pashwonbed }\end{array}$ & \begin{tabular}{|l} 
Dhasigare, \\
ChutroAmala
\end{tabular} & $\begin{array}{l}\text { Dhasigare, } \\
\text { Chutro }\end{array}$ & $\begin{array}{l}\text { Dhasigare, } \\
\text { Chutro }\end{array}$ \\
\hline 8 & Total HH members & 218 & 242 & 683 & 70 & 164 \\
\hline 9 & HH membership & One $\mathrm{M}$ or $\mathrm{F}$ & One $\mathrm{M}$ or $\mathrm{F}$ & One $\mathrm{M}$ or $\mathrm{F}$ & One $\mathrm{M}$ or $\mathrm{F}$ & One $\mathrm{M}$ or $\mathrm{F}$ \\
\hline 10 & E. C.members & 11 & 11 & 13 & 11 & 13 \\
\hline 11 & Women member in E.C. & At least 3 & At least3 & At least3 & At least3 & At least3 \\
\hline 12 & \begin{tabular}{|l|} 
Community \\
Development \\
Activities
\end{tabular} & $\begin{array}{l}\text { School, } \\
\text { College, } \\
\text { Electricity }\end{array}$ & \begin{tabular}{|l|} 
School, \\
Water supply \\
Temple
\end{tabular} & $\begin{array}{l}\text { School, } \\
\text { Rural road, } \\
\text { Temple }\end{array}$ & $\begin{array}{l}\text { Rural road, } \\
\text { Lighting, } \\
\text { Irrigation }\end{array}$ & No major \\
\hline
\end{tabular}

Source: Field Survey, 2018. 


\section{Methodology and Model Used}

The study is designed in accordance with the given objectivesand fully based on primary data. It followed both of descriptive as well as analytical methods. The population of the study is the total household members (63908 HHs)of FUGs (572) in the study area during the study periodin 2018 . So, firstly, 5 FUGs were selected using purposive sampling method by assuming the similar characteristics of the rest of other non-selected FUGs. Secondly, 125 household members were randomly selected as sample households (25householdsincluding 5 households from poor and 5 from disadvantaged groupsfrom each selected FUG) applying lottery method without replacement assuming that the selected households arealso properly representing the socio-economic diversities of the rest of non-selected households members.

The major instruments (tools) for collection of required data and information are household survey through a pre-tested structured questionnaire, formal focus group discussion with the member households of non-selected FUGs, informal key informant discussionwith the village level representativeson common issues, and participatory observation undertaken by the researcher himself in order to verify the collected information with the ground reality like lifestyle of the people, socio-economic characteristics, pattern of agricultural production, livestock keeping, forest condition, protection and management practicesin the study area. The field survey/visit was carried out by the researcher himself visiting door to door of the selected sampled households with the help of local representatives. Different types of statistical and econometric tools were used for data analysis and interpretation like various tables, percent, ratio, average, coefficient of correlation, multiple log regression, coefficient of determinants, adjusted coefficient of determinants, t-test, F-test, and D-W test etc.The collected data and information were organized and processed through the statistical computer software of 'Microsoft Excel' and 'SPSS - 25' for data analysis.

\section{Specification of the Variablesand Model}

The study used a multiple log-linear regression of people's participation as a dependent variable and it is the sum of people's participatory index (PPI) in forest protection and management activities as shown in table 2 .

Table 2: People's Participation Index (PPI)

\begin{tabular}{|c|l|c|l|}
\hline S.N. & \multicolumn{1}{|c|}{ Participatory Activities } & S.N. & \multicolumn{1}{|c|}{ Participatory Activities } \\
\hline $\mathbf{1}$ & Establishment of FUG & $\mathbf{1 4}$ & Soil conservation activities \\
\hline $\mathbf{2}$ & Formation of FUG Exe. Committee & $\mathbf{1 5}$ & Water / Watershed conservation activities \\
\hline $\mathbf{3}$ & Preparation of Constitution of FUG & $\mathbf{1 6}$ & Landslides management \\
\hline $\mathbf{4}$ & Preparation of Operation / Micro Plan & $\mathbf{1 7}$ & Floods management \\
\hline $\mathbf{5}$ & Nursery (Seeds and seedling) work & $\mathbf{1 8}$ & Environmental Protection activities \\
\hline $\mathbf{6}$ & Plantation (afforestation) work & $\mathbf{1 9}$ & Socio-economic development activities \\
\hline $\mathbf{7}$ & Thinning and pruning work & $\mathbf{2 0}$ & Income/employment generating activities \\
\hline
\end{tabular}




\begin{tabular}{|c|l|c|l|}
\hline $\mathbf{8}$ & Harvesting of forest product & $\mathbf{2 1}$ & Fund management \\
\hline $\mathbf{9}$ & Distribution of cost & $\mathbf{2 2}$ & Conflict management \\
\hline $\mathbf{1 0}$ & Distribution of benefit & $\mathbf{2 3}$ & Training, seminar and workshop \\
\hline $\mathbf{1 1}$ & Decision making activities & $\mathbf{2 4}$ & Audit, Monitoring and Evaluation \\
\hline $\mathbf{1 2}$ & Forest management activities. & $\mathbf{2 5}$ & Work of VFC / FUG with DoF / NGOs \\
\hline $\mathbf{1 3}$ & Forest fire control and management & \multicolumn{2}{|c|}{ Total scoring value of participation = 25 } \\
\hline
\end{tabular}

Note: Scoring value is 1 (one) from the answer yes otherwise 0 (zero)

However, PPI depends upon several independent socio-economic factors like the gross household income (GHY) of household member of the FUGs received from community forests by cash valuation of the tangible benefits of collecting timber, small timber, pole, firewood, fodder, grass, leaf litter, medicinal plants, herbs, fruits, and nuts etc. So, as the collection of the volume of those forest products increases, the gross household income (GHY) from community forests also increases. Similarly, other independent variables aresize of land holding (LDH), number of livestock keeping (LSK), distance between residence and community forests(DRCF), distance between residence and government forests (DRGF) and forest degraded index (FDI).Hence, the functional equation of the study is -

PPI $=\mathrm{f}(\mathrm{GHY}, \mathrm{LDH}, \mathrm{LSK}, \mathrm{DRCF}, \mathrm{DRGF}$, FDI $)$

Converting into linear form,

$\mathrm{PPI}_{t}=\beta_{0}+\beta_{1} \mathrm{GHY}_{t}+\beta_{2} \mathrm{LDH}_{t}+\beta_{3} \mathrm{LSK}_{t}+\mathrm{b}_{4} \mathrm{DRCF}_{\mathrm{t}}+\mathrm{b}_{5} \mathrm{DRGF}_{\mathrm{t}}+\mathrm{b}_{6} \mathrm{FDI}_{\mathrm{t}}+\mathrm{e}_{\mathrm{n}}$.

Taking natural log on both sides, the log-linear regression equation becomes as -

$\operatorname{lnPPI} I_{t}=\beta_{0}+\beta_{1} \ln \mathrm{GHY}_{t}+\beta_{2} \operatorname{lnLDH}{ }_{t}+\beta_{3} \ln \mathrm{LSK}_{t}+\mathrm{b}_{4} \ln \mathrm{DRCF}_{\mathrm{t}}+\mathrm{b}_{5} \operatorname{lnDRGF}_{\mathrm{t}}+\mathrm{b}_{6} \mathrm{FDI}_{\mathrm{t}}+\mathrm{e}_{\mathrm{n}}$

Where,

$\mathrm{PPI}_{\mathrm{t}}=$ People's participation index,

$\mathrm{GHY}=$ Gross household income from community forests,

$\mathrm{LDH}=$ Size of land holding,

LSK $=$ Number of livestock keeping,

$\mathrm{DRCF}=$ Distance between residence and community forests,

$\mathrm{DRGF}=$ Distance between residence and government forests,

FDI $=$ Forest Degraded Index

$\beta_{0}=$ Constant term,

$b_{I}=$ Parameters of independent variables (where, $i=1,2, \ldots n$ )

$\mathrm{e}_{\mathrm{n}}=$ Error term. 


\section{Hypotheses of the Study}

The hypothesis of the study is that there is a significant effect of given independent variables (GHY, LDH, LSK, DRCF, DRGF and FDI) on the dependent variable (PPI) that were tested by using t-test for the regression coefficients, F-test for the model (linearity of the fitted equation), and D-W test for auto-correlation at $0.01,0.05$ and 0.10 levels of significance as per the respective degrees of freedom.

\section{Data Presentation and Analysis}

In the study area, the participation of people in forestry programmeshas become very common, self-motivatedand widely spread through the FUGs. There is a system of compulsory participation of two persons (man and woman) from every member household in forestry programme. Non-member households of the FUGs are not allowed to use of forest and forest products.So, the participation of people in forestry programmescan be observed through various dimensions like nature and causes of participation, participation in training programmes,participation of women, poor and DAGs of people as given below.

\section{Nature of Participation}

The sample household members have got different nature of participation in forest protection and management work in the study area. Some households will get only membership but not attained any meeting. Some householdsdo attain meeting but do not give any own view to the meeting. Similarly, some households ask questions, giving own views and influence voice as shown in table 3.

Table 3: Nature of Participation of the Sample Households

\begin{tabular}{|c|l|c|c|}
\hline S.N. & Nature of People's Participation & Frequency & Percent \\
\hline 1 & Only membership & 8 & 6.4 \\
\hline 2 & Attending Meeting & 12 & 9.6 \\
\hline 3 & Asking questions & 77 & 61.6 \\
\hline 4 & Giving views & 17 & 13.6 \\
\hline 5 & Influence voice & 11 & 8.8 \\
\hline & Total & 125 & 100 \\
\hline
\end{tabular}

Source: Field Survey, 2018.

Table 3 reveals that the highest percent of participation is for asking questions and less percent is for only getting membership. However, 8.8 percent householdmember is influencing their voice in the FUGs. 


\section{Causes of Participation}

Basically, rural communityparticipate in forest protection and management work with three different motives such asto get the basic forest products like timber, pole, fuel wood, fodder, grass, leaf litter, fruits, herbs and other NTFPs; to generate income and employment opportunities, and to maintain environmental stability and ecological balance. The basics causes of people's participation in the study area are shown in given table.

Table 4: Causes of Participation of the Sample Households

\begin{tabular}{|c|l|c|c|}
\hline S.N. & \multicolumn{1}{|c|}{ Causes of People' Participation } & Frequency & Percent \\
\hline 1 & Compulsory membership & 6 & 4.8 \\
\hline 2 & As others became member & 8 & 6.4 \\
\hline 3 & Socio-economic benefits & 20 & 16.0 \\
\hline 4 & Regeneration of forests & 65 & 52.0 \\
\hline 5 & Getting more forest products & 16 & 12.8 \\
\hline 6 & Restricted for non-members & 10 & 8.0 \\
\hline & Total & 125 & 100 \\
\hline
\end{tabular}

Source: Field Survey, 2018.

Table4 reveals that most of the households participate for regeneration of forests (52 percent) and followed by socio-economic benefits (16 percent) andgetting more forest products (12.8 percent). The lowest percent is forcompulsory membership (4.8 percent) of the FUGs.

\section{Participation in TrainingProgrammes}

Training is considered as a part of a human wealth. It helps trainees to clearly understand and make wide vision of the matter with building well confidence. So, training for all members of FUGs could help better planning and implementation of the forestry programmes. So, in order to develop qualitative human resources, training on various forests related activities should be provided by the forest department and other stakeholders. The household members should be provided orientation, short term and medium term of theoretical, practical and technical trainingprogrammes on different issues like planning, plantation, thinning, pruning, harvesting of forest products, coordination and better management etc. It could help the forest users to understand their roles and responsibilities in the FUGs. A picture of participation of sampled households in training programme can be shown with the help of table 5. 
10 | The Economic Journal of Nepal (Issue No. 149)

Table 5: Participation of SHHs in Different Training Programmes

\begin{tabular}{|c|l|c|c|}
\hline S.N. & \multicolumn{1}{|c|}{ Participation Training Programmes } & Frequency & Percent \\
\hline 1 & Never taken & 22 & 17.6 \\
\hline 2 & One time & 31 & 24.8 \\
\hline 3 & Two times & 42 & 33.6 \\
\hline 4 & Three times & 10 & 8.0 \\
\hline 5 & Four times & 8 & 6.4 \\
\hline 6 & Five times & 7 & 5.6 \\
\hline 7 & More than five times & 5 & 4.0 \\
\hline & Total & 125 & 100 \\
\hline
\end{tabular}

Source: Field Survey, 2018.

Table 5 reveals that the highest percent of sample households (33.6 percent) participated two times in various forestry programmes followed by one time ( 24.8 percent). The more than five times participated sample household is only 4 percent. In addition, there are still 17.6 percent sample households that have not participated in any king of trainingprogramme.

\subsection{Women Participation}

Women as traditionally real users of the forest products could play a vital, significant and constructive role in optimal useand sustainable development in forest protection and management work. In many cases, women are primary collectors of forest products for domestic and commercial uses. In rural Nepal, women are fully involved in agriculture, livestock keeping, collection of firewood as main energy source, fodder, grass, herbs and medicinal plants etc. which are closely connected to the forests. They also have several cultural and religious festivals where forests are involved. Most of the forest related activities have performed by women. So, any shortage of forest products makes them to walk more distance to get those forest products. But, the collection of these forest products can have a tremendous impact on the condition of forests and availability of forest products.

In the study area, it is believed that women have better knowledge than men about use and availability of various forest products in different seasons. Since women are most closely associated with the forest products and forest management work right from the beginning, the voices of women should be listened and respected by all men members. Hence, women should be encouraged to more participate in the user groups and their decision making should be given an adequate importance. It is also generally realized that there must be an adequate number of women members in user groups. Women active and full participation is essential to success community forest management. The Master Plan for Forestry Sector -1998 gave the guideline to have 33 percent of the women's participation in CFUG formation at a local levelof women in user groups. But, in the study area, there are more than 50 percent of women participating in various forestry activities as shown in table 6 . 
Table 6: Women Participation in Various Activities

\begin{tabular}{|c|l|c|c|c|c|}
\hline S.N. & \multicolumn{1}{|c|}{ Women participation } & Female & Percent & Male & Percent \\
\hline 1 & As FUGmembers & 72 & 57.6 & 53 & 42.4 \\
\hline 2 & As executive committee member & $\begin{array}{c}\text { On } \\
\text { average 6 }\end{array}$ & 54.55 & $\begin{array}{c}\text { On } \\
\text { average 7 }\end{array}$ & 45.45 \\
\hline 3 & Preparation of working plan & 14 & 35.90 & 25 & 64.10 \\
\hline 4 & In forest extraction activities & 69 & 55.2 & 56 & 44.8 \\
\hline 5 & In forest management Activities & 65 & 52.0 & 60 & 48.0 \\
\hline
\end{tabular}

Source: Field Survey, 2018.

The table 6 reveals that there is a better number of women participation in various forestry activities from every sample households. Women participation in forest extraction activities is highest (52.8 percent) and thereby management activities(20.8 percent). There were 8 percent women found in participation as FUG member and working plan preparation. There is more than 33 percent of women participation in the FUGs in the study area. There are 11 to 13 members in 'Executive Committee' of sampled FUGs in which 3 members are women (table1). Similarly, the level of participation and level of activities of women in forestry activities are also found increasing as shown in table 7.

Table 7: Trend of Women Participation

\begin{tabular}{|c|c|c|c|c|c|}
\hline S.N. & Women Participation & \multicolumn{2}{|r|}{ Levels } & \multirow{2}{*}{$\begin{array}{c}\text { Frequency } \\
110\end{array}$} & \multirow{2}{*}{$\begin{array}{c}\text { Percent } \\
88\end{array}$} \\
\hline \multirow{4}{*}{1} & \multirow{4}{*}{ Level of Participation } & $a$ & Increase & & \\
\hline & & $b$ & Moderate & 15 & 12 \\
\hline & & C & Decrease & 0 & 0 \\
\hline & & \multicolumn{2}{|r|}{ Total } & 125 & 100 \\
\hline \multirow{4}{*}{2} & \multirow{4}{*}{ Level of Activities } & a & Active & 95 & 76 \\
\hline & & b & Moderate & 20 & 16 \\
\hline & & $\mathrm{c}$ & Passive & 10 & 8 \\
\hline & & \multicolumn{2}{|c|}{ Total } & 125 & 100 \\
\hline
\end{tabular}

Source: Field Survey, 2018.

The table7 shows that the level of women participation in forestry activities is gradually increasing reported by 88 percent sample households. Likewise, the level of women activities in forestrywork isalso gradually being more active reported by 76 percent sample households. Despite, women have to look after domestic task, agricultural work, grazing, and care of family members, their participation in forest management is being at satisfactory level. Women in the study area also expressed that the availability of fuel wood, fodder, grass, leaf litter and source of water have also been increased after the forest management work through the FUGs that has made their life more easier than before. Hence, it shows that both level of women participation and activities in forestry work is at satisfactorily level. 
12 | The Economic Journal of Nepal (Issue No. 149)

\section{Participation of Poor and Disadvantaged Groups (DAGs)}

The rural poor people and DAGs of the society are also the prime users of forests and forest products as they do collect more fuel wood, fodder, grass, leaf litter, herbs and NTFPs for their daily subsistence and livelihood. So, the better livelihood of them directly depends upon the sustainable management of community forests. Hence, they have to be directly involved in forestry activities for their own subsistence. However, there is not satisfactory level of their involved in the forestry programmesdue to socio-economic and cultural suppression in the society. However, their participation and activities in forestry activities are gradually increasing in the study area but not at satisfactory level as shown in table 8 .

Table 8: Trend of Poor and DAGsParticipation

\begin{tabular}{|c|c|c|c|c|c|}
\hline S. N. & Poor & & Level & Frequency & Percent \\
\hline \multirow{4}{*}{1} & \multirow{4}{*}{ Level of Participation } & $a$ & Increase & 93 & 74.4 \\
\hline & & b & Moderate & 32 & 25.6 \\
\hline & & c & Decrease & 0 & 0 \\
\hline & & \multicolumn{2}{|c|}{ Total } & 125 & 100 \\
\hline \multirow{4}{*}{2} & \multirow{4}{*}{ Level of Activities } & a & Active & 83 & 66.4 \\
\hline & & b & Moderate & 42 & 33.6 \\
\hline & & c & Passive & 0 & $\mathrm{O}$ \\
\hline & & \multicolumn{2}{|c|}{ Total } & 125 & 100 \\
\hline
\end{tabular}

Source: Field Survey, 2018.

The table 8 reveals thatthe level of rural poor people and DA Gsparticipation in forestry activities is gradually increasing reported by 74.4 percent sample households. Similarly, the level of activities in forestry work isalso gradually being more active reported by 66.4 percent sample households. Hence, it shows that both level of participation and activities in forestry work is not at disappointed level. The poor people and DAGs were also reported that the FUGs have also gradually included them in decision making activities as well.

\section{Empirical Analysis of People's Participation}

\section{Correlation Analysis}

Correlation analysis measures the quantitative relationship(association) between two or more continuous variables. It is an assessment that measures both the direction and strength of a linear relationship between two or more variables.Correlation of coefficient between two variables is the symmetric as the coefficient value between $X$ and $Y$ or $Y$ and $X$ variables remain the same. The study used Pearson's correlation coefficient as a test statistic. Pearson's correlation to analyze the degree of relationship between people's participation index (PPI) in the study area with its major determinants like gross household income (GHY), size of land holding 
(LHD), number of livestock keeping (LSK), distance between residence and community forests (DRCF), distance between residence and government forests (DRGF), and forest degraded index (FDI).Pearson's coefficients of correlation have been presented as below.

Table 9: Correlation Matrix between Dependent and Independent Variables

\begin{tabular}{|c|c|c|c|c|c|c|c|}
\hline Variables & PPI & GHY & LDH & LSK & DRCF & DRGF & FDI \\
\hline PPI & 1 & & & & & & \\
\hline $\begin{array}{l}\text { GHY } \\
\text { (p- value) }\end{array}$ & $\begin{array}{c}0.814 \\
(0.003)^{*}\end{array}$ & 1 & & & & & \\
\hline LDH ( $p$ - value) & $\begin{array}{c}0.542 \\
(0.082) * * * \\
\end{array}$ & $\begin{array}{c}0.357 \\
(0.000)^{*} \\
\end{array}$ & 1 & & & & \\
\hline LSK ( $\quad$ - value) & $\begin{array}{c}0.589 \\
(0.041)^{* *}\end{array}$ & $\begin{array}{c}0.726 \\
(0.000)^{*}\end{array}$ & $\begin{array}{c}0.493 \\
(0.000)^{*}\end{array}$ & 1 & & & \\
\hline DRCF ( $p$ - value) & $\begin{array}{c}-0.454 \\
(0.001)^{*}\end{array}$ & $\begin{array}{c}0.673 \\
(0.000)^{*}\end{array}$ & $\begin{array}{c}0.321 \\
(0.000)^{*}\end{array}$ & $\begin{array}{c}0.412 \\
(0.000)^{*}\end{array}$ & 1 & & \\
\hline DRGF ( $p$ - value) & $\begin{array}{c}0.313 \\
(0.141) \\
\end{array}$ & $\begin{array}{c}0.314 \\
(0.000)^{*}\end{array}$ & $\begin{array}{c}0.313 \\
(0.000)^{*}\end{array}$ & $\begin{array}{c}0.279 \\
(0.000)^{*} \\
\end{array}$ & $\begin{array}{c}0.243 \\
(0.000)^{*} \\
\end{array}$ & 1 & \\
\hline ( $p$ - value) & $\begin{array}{c}0.442 \\
(0.000)^{* *}\end{array}$ & $\begin{array}{c}0.462 \\
(0.000)^{*}\end{array}$ & $\begin{array}{c}0.307 \\
(0.000)^{*}\end{array}$ & $\begin{array}{c}0.302 \\
(0.000)^{*}\end{array}$ & $\begin{array}{c}0.371 \\
(0.000)^{*}\end{array}$ & $\begin{array}{c}0.617 \\
(0.000)^{*}\end{array}$ & 1 \\
\hline
\end{tabular}

Note: Singleasterisk* is at 0.01 level, double asterisks** at 0.05 level, andtriple asterisks*** at 0.10 levelof significance.

\section{Source: Author's calculation.}

Table 9 shows that there is a positive correlation between PPI andGHY with the coefficient of 0.814 that meansthere is a fairly strong positive relationshipbetween them and it is significant at one percent level as p-value ( 0.003$)$ is less than the $\alpha$-value (0.01 percent). Similarly, the coefficient of correlation between PPI and LHDis 0.542 which shows that both of them are positive and highly correlated to each other and it is significant at 10 percent level as p-value $(0.082)$ is less than the $\alpha$-value ( 0.10 percent). Similarly, the coefficient of correlation between PPI and LSK is 0.498 which shows that both of them have positive and moderate correlation to each other and it is also significant at 5 percent level as p-value (0.041) is less than the $\alpha$-value (0.05 percent). Again, the coefficient of correlation between PPI and DRCF is - 0.498 which shows that both of them have negative and moderate correlation to each other and it is significant at one percent level as p-value (0.001) is less than the $\alpha$-value ( 0.01 percent).

The coefficient of correlation between PPI and DRGF is 0.313 which shows that both of them have positive but weak correlation to each other. But it is insignificant even at tenpercent level as p-value (0.141) is higher than the $\alpha$-value ( 0.10 percent). Finally,the coefficient of correlation between PPI and FDI is 0.442 which shows that both of them have positive and moderate correlation to each other and it is also significant at five percent level as p-value (0.036) is less than the $\alpha$-value ( 0.05 percent).Finally, the coefficient of multiple correlation 
14 | The Economic Journal of Nepal (Issue No. 149)

among all given variables is 0.537 which shows that there is a positive and moderate correlation among them and it is significant only at five percent level as p-value $(0.039)$ is less than the $\alpha$-value ( 0.05 percent).

\section{Regression Analysis}

The regression analysis shows the role in magnitude of given independent variables to the dependent variable. In the study, people's participation is taken as the dependent(response) variable whereas some socioeconomic, physical and environmental factors are taken as independent(explanatory) variables like gross household income from community forests (GHY),size of land holding (LDH), number of livestock keeping (LSK), distance between residence and community forests (DRCF), distance between residence and government forests (DRGF), and forest degradeindex(FDI) in the study area. Besides, there might be some other variables that may significantly affect to the process of people's participation but that cannot be taken in the model due to some constraints of the study.Therefore, a log-linear multiple regression model is drawn in order to examine the percentchange in independent (explanatory) variablesto the percent change in dependent variable as shown in table 10.

$$
\begin{aligned}
\operatorname{lnPPI}_{t}= & \beta_{0}+\beta_{1} \ln \mathbf{G H Y}_{t}+\beta_{2} \ln \mathbf{L D H}_{t}+\beta_{3} \ln \mathrm{LSK}_{\mathrm{t}}+\mathrm{b}_{4} \ln \mathrm{DRCF}_{\mathrm{t}}+\mathrm{b}_{5} \ln \mathrm{DRGF}_{\mathrm{t}} \\
& +\mathrm{b}_{6} \ln \mathrm{FDI}_{\mathrm{t}}+\mathrm{e}_{\mathrm{n}}
\end{aligned}
$$

Table10: Results of Regression Analysis for Determinants of PPI

\begin{tabular}{|l|c|c|c|c|c|}
\hline \multicolumn{1}{|c|}{ Variables } & $\begin{array}{c}\text { Expected } \\
\text { Sign }\end{array}$ & Coefficients & S, E. & t-value & P - value \\
\hline Constant $\left(\beta_{0}\right)$ & & 2.338 & 0.253 & 2.252 & 0.061 \\
\hline GHY $\left(\beta_{1}\right)$ & + & 0.761 & 0.421 & $-1.542 *$ & 0.010 \\
\hline LDH $\left(\beta_{2}\right)$ & + & 0.189 & 0.027 & $-1.520 * * *$ & 0.062 \\
\hline LSK $\left(\beta_{3}\right)$ & + & 0.215 & 0.031 & $-0.051^{* *}$ & 0.035 \\
\hline DRCF $\left(\beta_{4}\right)$ & - & -0.484 & 0.121 & $-1.452 *$ & 0.000 \\
\hline DRGF $\left(\beta_{5}\right)$ & + & 0.342 & 0.311 & 1.419 & 0.120 \\
\hline FDI $\left(\beta_{6}\right)$ & + & 0.362 & 0.027 & $1.318^{* *}$ & 0.041 \\
\hline $\begin{array}{l}R^{2}=0.766, \text { Adj. } R^{2}=0.681, \text { No of Observation }=125 \\
\text { F-value }=1.619^{* *} \quad \text { P-value }=0.000 \quad D-W \text { value }=1.173 * *\end{array}$ \\
\hline
\end{tabular}

Note: Single asterisk* Significant at $1 \%$, double asterisks $* *$ Significant at $5 \%$, and triple asterisks $* * *$ Significant at $10 \%$.

\section{Source:Author's calculation.}

Table 10 reveals that 76.6 percent of the total variation in PPI is explained by the variation in the given all independent (explanatory) variables like GHY, LDH and LSK, DRCF, DRGF and FDI. Similarly, 68.1 percent of the total variation in PPI is explained by the given fitted regression. Again the P-value (0.000) for overall goodness of fit in the model is lesser than $\alpha$ value $(\alpha=0.01)$ so that the model is statistically significant even at one percent level 
of significance. Hence, it could be concluded that the regression equation is significant by rejecting null hypothesis of the study. Moreover, the p-value of auto-correlation (D-W) is less than its $\alpha$-value [i.e. p-value $(0.031)<\alpha$-value $(0.05)$ ]. Hence, it concludes that the error terms are said to be no positively auto-correlated in the model at five percent level of significant.

Similarly, the coefficients of all given predictors $\left(\beta_{\mathrm{i}}\right)$ in the model have become expected sign. The table further shows that as one percent increase in gross household income (GHY), that leads to increase in PPI by 0.761 percent or if there is 10 percent increases in GHY, it leads to increase in PPI by 7.61 percent. The coefficient of GHYis statisticallysignificant even at one percent level as the p-value (0.010) of the predictor GHY $\left(\beta_{1}\right)$ is equal to its $\alpha$-value (0.010).It shows that GHY is highly influencing in people's participation in forests protection and management work in the study area.

Similarly, the table shows that as one percent increases in LHD, that leads to increase in PPI by 0.189 and it is statisticallysignificant at 10 percent level as the p-value $(0.062)$ of the predictor LHD $\left(\beta_{2}\right)$ is less than its $\alpha$-value (0.10). Similarly, as one percent increases in SLK that leads to increase in PPI by 0.215 percent and it is statisticallysignificant at 5 percent level as the p-value of the predictor SLK $\left(\beta_{3}\right)$ is less than its $\alpha$-value [i.e. p-value $(0.035)<$ $\alpha$-value(0.05)]. Again, as 1 percent decreases in DRCF that leads to increase in PPI by 0.484 percent and it is statisticallysignificant at even 1 percent level as the p-value of the predictor DRCF $\left(\beta_{4}\right)$ is less than its $\alpha$-value [(i.e. p-value $(0.000)<\alpha$-value $(0.01)$ ]. Again, as 1 percent decreases in DRGF that leads to increase in PPI by 0.342 percent and it is statisticallyinsignificant even at 10 percent level as the p-value of the predictor DRGF $\left(\beta_{5}\right)$ is higher than its $\alpha$-value [(i.e. p-value $(0.130)<\alpha$-value $(0.10)$ ].Finally, as 1 percent increases in FDI that leads to increase in PPI by 0.362 percent and it is statisticallysignificant at 5 percent level as the p-value of the predictor DRCF $\left(\beta_{6}\right)$ is less than its $\alpha$-value [(i.e. $p$-value $(0.05)<\alpha$-value $(0.041)]$.

\section{Conclusion}

PFM has been taken as anappropriate means by government in forest protection and management work, and empowering the local people that would help to achieve equitable and sustainable use of forest resources. The principle aim of PFM is to provide direct benefits to rural people byinvolving them in all stages of forestry activities from decision making to harvesting of forest products.Local people are to be involved in forestry programmesin such a way that they are fully clear about their needs, responsibilities, government policies and programmes. The responsibility should be permanent in nature and legalized as the local people will continue to protect and manage the forests and forest products for their present and future needs. If people are assured that they are getting sustainable benefits from the forests both in short and long term, people will easily involve in forest protection and management work. Accessibility of forest resources is one of the main factors in determining the interest of local forests users in forestry programmes.Therefore, people's participationis taken as thekeyand best ways to success and sustains their livelihoods,socio-economic development and reduction of environmental degradationthrough the proper protection and management 
of forests and forest products. As forest is one of the most renewable natural resource of the study area, CFP is a viable option for conserving, improving, using and managing of the natural resources in Nepal where women could play a significant role in this endeavor. As the rural poor people and DAGs of the society are also the prime users of forests and forest products, they have to be directly involved in forestry activities for their daily subsistence and livelihood.However, the participation and activities of women, poor people and DAGs in forestry activities are gradually increasing in the study area.

\section{References}

Acharya, K. P. (2003). Twenty-four years of community forestry in Nepal.Paper presented onProject Evaluation Workshop on Community Forestry.Kathmandu:Department of Forest, His Majesty's Governmeent, Nepal.

Anon (1994).Forest for people. In B. D. Patric, (Ed.), FAO, RAPA Publication.

Arnold, J. E. M. \&G. J. Campbell (1985). Collective management of Hill forests in Nepal: The community forestry development project, Proceedings of National Academy of Sciences. Annapolis.

CBS (Central Bureau of Statistics) (2014).Statistical Year Book, Kathmandu: CBS.

DFO (District Forest Office) (2018). Profile of District Forest Office, Kavrepalanchok.DFO.

DoF (Department of Forest) (2018). Community Forest Bulletin. Kathmandu: Community Forest Division, DoF.

FAO(2000).Development of National Level Criteria and Indicators for the Sustainable Management of Dry Forest of Asia,Asia and Pacific Forestry Commission.Bhopal, India: RAP Publication

Gilmour, D. A. \& Fisher, R. J. (1991). Villagers, forests and foresters: The philosophy, process and practice of community forestry in Nepal.Kathmandu: Sahayogi Press.

Gilmour, D. A., King, C. G.,\& Fisher, R. J. (1987). Action research into social-economic aspects of forest management.Role of Forest Research in Solving Socio-economic Problems in the Himalayan Region.Proceedings of the IUFRO symposium.Peshawar, Pakistan: Forest Research Institute.

Houghton, R. A. (1990). The global effects to tropical deforestation. Environmental Science and Technology, 24(4): 414-424.

ICIMOD (International Centre for Integrated Mountain Development) (1995). Community Forestry: The Language of Life. Report of the first community forestry user's group workshop, organized by ICIMOD, Trees and People Programme, Kathmandu: Nepal, 22-27 May, 1995.

Joshi, A. L. (1997). Empowering local users in the forest management of Nepal.Sahabhagita, $1(2), 49-68$. 
Joshi, D. B. (2004), Programme planning in community forestry.Community Forestry Bulletin. 11, 20-33.

Kandel, B. R. \&Subedi, R. (2004), Pro-poor community forestry: Some initiatives from the field. Paper presented at the $4^{\text {th }}$ national workshop on community forestry, Kathmandu: DoF, HMG, Nepal.

Karki, M. (2003). Joint and community forest in South Asia: Lesson learned road blocks and future prospects. Paper presented at the joint forest management in Pakistan. Peshawar: July 30-31, 2003.

Mehta, K. S. (2001). Participatory in forest management: A case study of Uttarkhand'.In G. P. Mishra and B. K. Bajpai (Eds.).Community Participation in Natural Resource Management. (315-328). Jaipur, India: Rewat Publication.

Nadkarni, M. V.(1989). The political economy of forest use and management. New Delhi:Sage Publication.

Ranjit, Y. (2014). Determination of people's participationin forest protection and management: A study in Kaski.Economic Journal of Development Issues, 17\&18 (1\&2),175-186

Ranjit (2016).Integratingeconomic benefits with participatory forest management in Kaski District. The Economic Journal of Nepal, 38 (3\&4), 17-24

Shrestha, R. B.\&Sharma, A. R. (2004), Sustainable management of community forests: Contribution towards Millennium Development Goals. Paper presented at the $4^{\text {th }}$ National Workshop on community forestry, 4-6 August, Kathmandu: DoF, HMG, Nepal.

Thompson, J. (1995), Participatory approaches in government bureaucracies: Facilitating the process of institutional change.World Development, 23 (9), 1521-1534. 